\title{
Effect of Using Multiple Intelligences Activities on Self-Perceptive and Learning Some Basic Judo Skills for Inexperienced Judo Players
}

\author{
Eman Askar*
}

\begin{abstract}
This research aims to find the effect of using some multiple intelligences activities in teaching basic judo skills and its effect on developing self-perceptive which include (physical skill-physical condition- self physical value-physical power) on judo beginner Players. Researcher used the experimental method, the experimental design with a tribal measurement of two groups, one experimental and the other control.

The sample was(60) Students from the Second grade students, Faculty of Physical Education for Girls - Zagazig University divided equally into two groups (experimental-control).

After applying the research there are a statistically significant differences between later measurements of the experimental, control group for experimental group in self-perceived standard, statistically significant differences between later, previous of the control group for later measurements self-perceptive standard.
\end{abstract}

Keywords: multiple intelligences activities- self-perceptive- basic judo skills-inexperienced judo players- experimental method

\section{Introduction}

$\mathrm{M}$ any psychological theories are concerned with explaining the reasons behind the difference between students in learning methods such as learning-style theory and multi intelligences theory [1].

Judo is considered a competitive sport aims to develop the elements of comprehensive fitness for both men and women which is only achieved through educational programs, training durations and competitive activities.

Judo skills is done in a physical, muscular and mental manner which means that motivate skill is related to mental skill and it's hard to create boundaries between them [2].

Through the researcher job in teaching judo to second year university students she noticed that there are a difference in application of judo skills

* Lecturer, Faculty of Physical Education for Girls, Zagazig University, Egypt. due to non-confidence in students' abilities which will effect on their performance.

So the researcher found that using multiple intelligence activities as teaching strategic will improve their teaching means.

Multiple intelligence activities is ideal in teaching order as provide brain with motivate way to judo beginner students and also compactable with judo requirements to improve self-perceptive.

The researcher found that there rareness in selfperceptive researches in general and especially in judo sport.

\section{Research Problem}

The researcher noticed, through teaching judo to students, decreiesing of performance skill level The researcher thinks that this because using traditional method in teaching judo.so she suggested using multiple intelligences activities 
in teaching to improve the performance skill level.

\section{Aim of the Study}

1. To find the effect of using some multiple intelligences activities in teaching basic judo skills and its effect on developing self-perceptive which include (physical skill- physical condition- self physical value-physical power) on judo beginner Players.

2. Performance level of some basic skills (fall down (Ukemie)-upper playing (Nage.waza)ground playing (Katame.waza) on judo beginner.

\section{Method}

Researcher used the experimental method, the experimental design with a tribal measurement of two groups, one experimental and the other control.

\section{Population and Sample}

The selection of the research community done by intentional way from the Second grade students, Faculty of Physical Education for Girls - Zagazig University for the academic year (2011/2012). (60) Students were divided equally into two groups (experimental- control. The researcher has a homogeneity them in variables (Age - Height - Weight - a measure of multiple intelligences - self-perceived standard) to determine the effect of experimental variables.

\section{Data Collecting Tools}

1. Multiple intelligences standard

2. Self-perceptive standard

\section{Skill Tests}

Performance skill level

A committee of three faculty members held a test at the end of the first semester of the Second grade, the test degree distributed on (fall downupper playing skills-ground playing skills) . the total exam scores (15) degree is divided as follows (3) fall down- (9) upper playing skills(3) ground playing skills the average degrees of this Committee was taken with form to assess the performance skills level.

\section{Validity}

The researcher used distinction validity to verify the selected tests validity, and the calculated $\mathrm{T}$ value was at $0.05=2.02$.

\section{Reliability}

The reliability was calculated by applying "TestRe test". The correlation coefficient was 0.632 .

\section{The Pre Measurements}

The Inthrpomitric measurments and standards are measured from 4-8/3/2012.

\section{Applying the Program}

The researcher applied the suggested program for 12 weeks, one times a week and each lesson took 90 minutes, from $11 / 3 / 2012$ to $31 / 5 / 2012$, the researcher was teached to the experimental group using multiple intelligences activities , and was teached to the control group using the traditional method.

\section{The Post Measurements}

The post measurements of all variables studied were conducted from $3 / 6 / 2012$ to $5 / 6 / 2012$. 
Table (1)

Difference between later, previous measurements for experimental group in self-perceptive standard No=30

\begin{tabular}{|c|c|c|c|c|c|c|c|c|}
\hline \multirow{2}{*}{\multicolumn{2}{|c|}{ Variables }} & \multicolumn{2}{|c|}{$\begin{array}{c}\text { Previous } \\
\text { measurements }\end{array}$} & \multicolumn{2}{|c|}{$\begin{array}{c}\text { Later } \\
\text { measurements }\end{array}$} & \multirow{3}{*}{$\begin{array}{c}\text { Difference } \\
3.96 \\
\end{array}$} & \multirow{3}{*}{$\begin{array}{c}\mathrm{T} \\
\text { value }\end{array}$} & \multirow{3}{*}{$\begin{array}{c}\begin{array}{c}\text { Improving } \\
\text { value }\end{array} \\
25.07 \% \\
\end{array}$} \\
\hline & & average & torsion & average & Torsion & & & \\
\hline \multirow{5}{*}{$\begin{array}{c}\text { Self- } \\
\text { perceptive }\end{array}$} & Physical skill & 15.79 & 2.62 & 19.75 & 3.71 & & & \\
\hline & $\begin{array}{l}\text { Physical } \\
\text { condition }\end{array}$ & 15.49 & 2,28 & 19.80 & 3.12 & 4.31 & 27.63 & $27.82 \%$ \\
\hline & $\begin{array}{c}\text { Physical } \\
\text { gravity }\end{array}$ & 17.34 & 3.15 & 20.90 & 4.19 & 3.56 & 18.42 & $20.52 \%$ \\
\hline & $\begin{array}{c}\text { Physical self- } \\
\text { value }\end{array}$ & 14.43 & 2.64 & 21.81 & 4.75 & 7.37 & 18.81 & $51.07 \%$ \\
\hline & Physical skill & 14.41 & 2.58 & 22.25 & 4.36 & 7.84 & 23.98 & $54.41 \%$ \\
\hline
\end{tabular}

As shown from table there is significant for experimental group to later measurements difference between later, previous measurements in self-perceptive

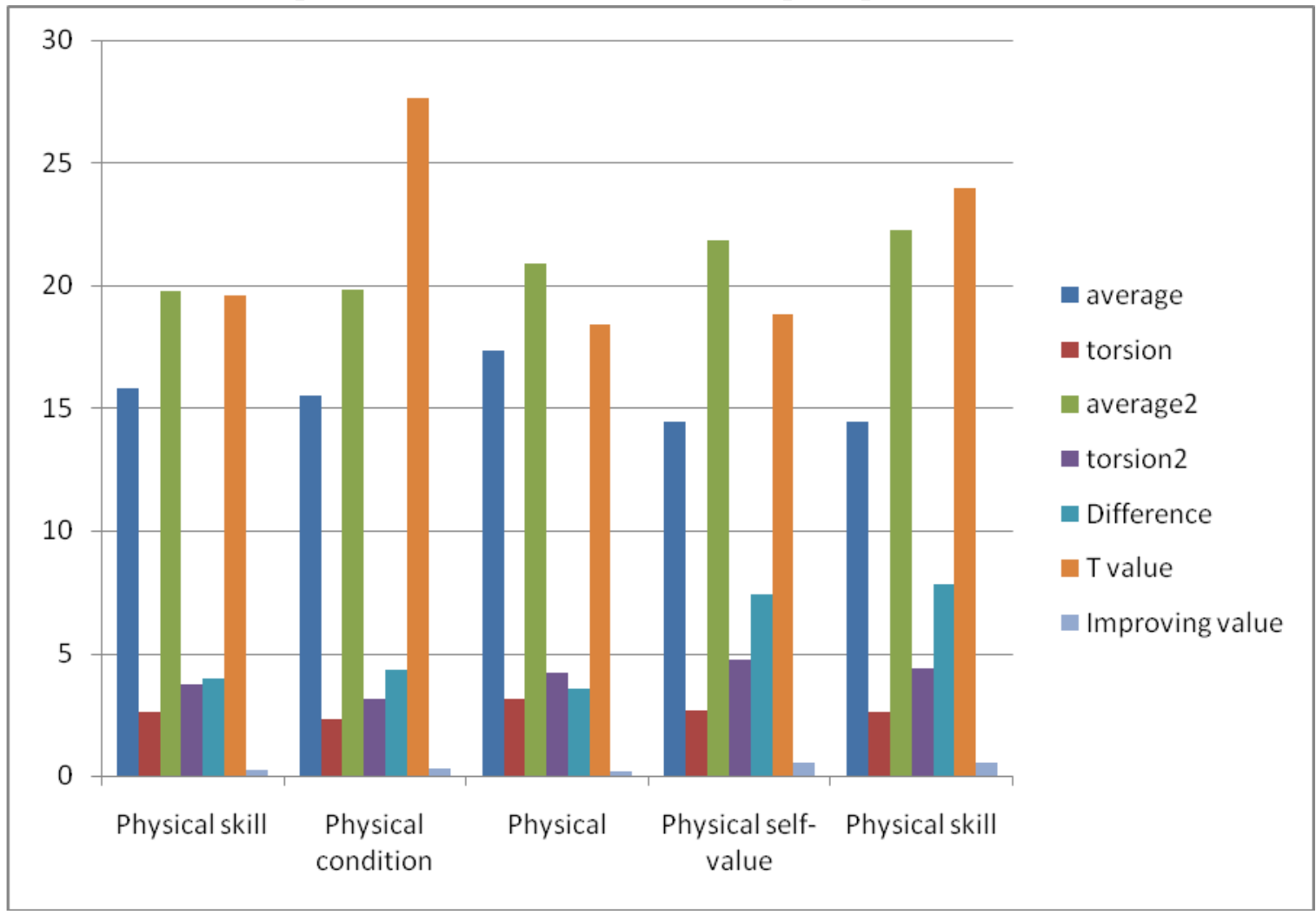


Table (2)

Difference between later, previous measurements for control group in self-perceptive standard No=30

\begin{tabular}{|c|c|c|c|c|c|c|c|c|}
\hline \multirow{2}{*}{\multicolumn{2}{|c|}{ Variables }} & \multicolumn{2}{|c|}{$\begin{array}{c}\text { Previous } \\
\text { measurements }\end{array}$} & \multicolumn{2}{|c|}{$\begin{array}{c}\text { Later } \\
\text { measurements }\end{array}$} & \multirow{3}{*}{$\begin{array}{c}\text { difference } \\
1.60\end{array}$} & \multirow{3}{*}{$\begin{array}{c}\mathrm{T} \\
\text { value }\end{array}$} & \multirow{3}{*}{$\begin{array}{c}\begin{array}{c}\text { Improving } \\
\text { value }\end{array} \\
9.97 \%\end{array}$} \\
\hline & & \multirow{2}{*}{$\begin{array}{c}\text { average } \\
16.05\end{array}$} & \multirow{2}{*}{$\begin{array}{c}\text { Torsion } \\
2.34 \\
\end{array}$} & \multirow{2}{*}{$\begin{array}{c}\text { average } \\
17.65\end{array}$} & \multirow{2}{*}{$\begin{array}{c}\text { torsion } \\
2.71 \\
\end{array}$} & & & \\
\hline \multirow{5}{*}{$\begin{array}{c}\text { self- } \\
\text { perceptive }\end{array}$} & Physical skill & & & & & & & \\
\hline & $\begin{array}{l}\text { Physical } \\
\text { condition }\end{array}$ & 15.87 & 2,28 & 18.90 & 2.82 & 3.03 & 30.21 & $19.09 \%$ \\
\hline & $\begin{array}{l}\text { Physical } \\
\text { gravity }\end{array}$ & 17.03 & 3.14 & 18.67 & 3.43 & 1.64 & 30.45 & $9.63 \%$ \\
\hline & $\begin{array}{c}\text { Physical self- } \\
\text { value }\end{array}$ & 14.25 & 2.44 & 16.40 & 2.95 & 2.15 & 22.70 & $15.09 \%$ \\
\hline & Physical skill & 14.20 & 2.38 & 17.05 & 2.98 & 2.85 & 25.07 & $20.07 \%$ \\
\hline
\end{tabular}

As shown from table there are significant for control group to later measurements in selfdifference between later, previous measurements perceptive standard

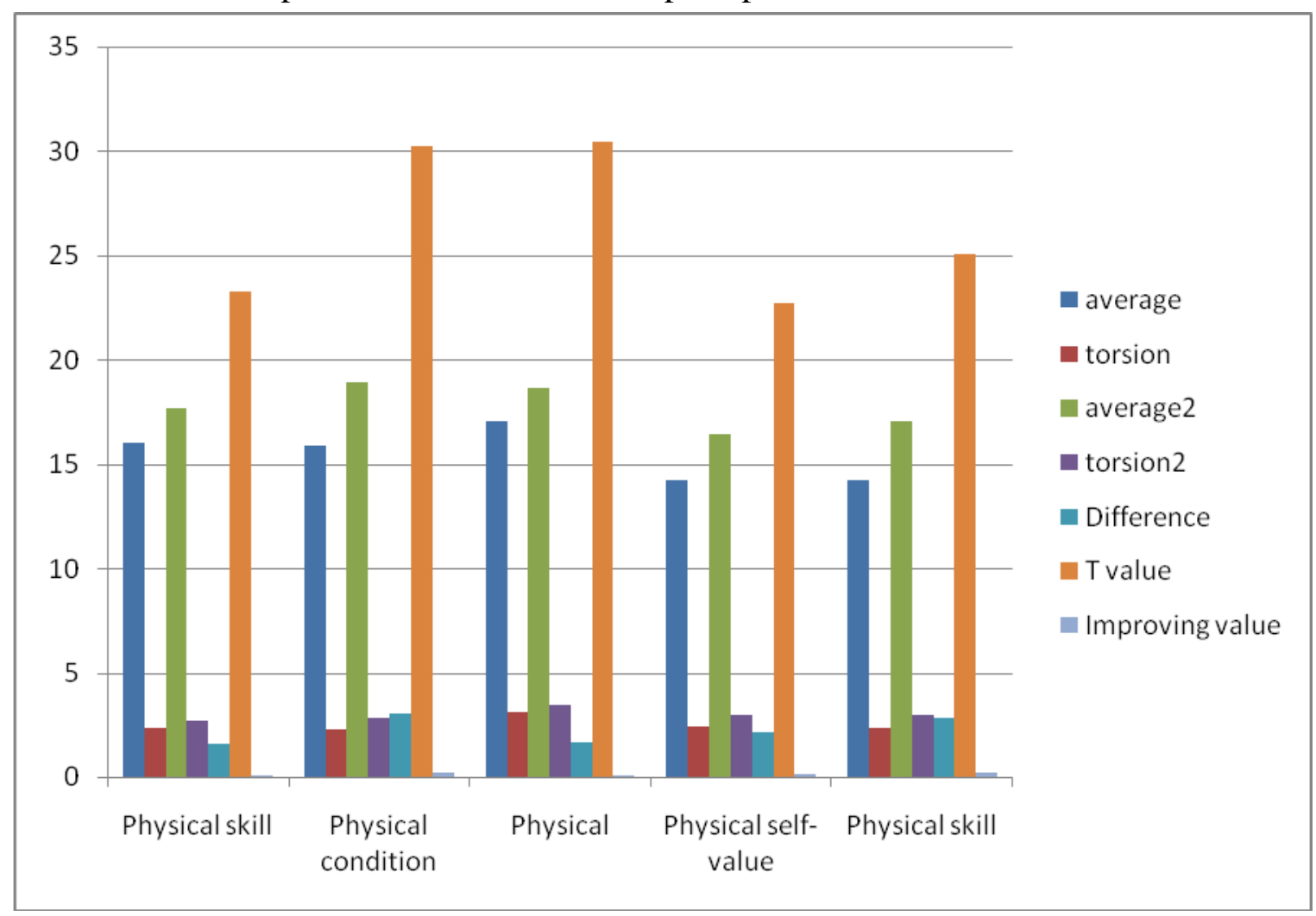

Table (3)

Difference between later, previous measurements for control, experimental groups in self-perceptive standard $N 1=N 2=30$

\begin{tabular}{|c|c|c|c|c|c|c|c|}
\hline \multirow{2}{*}{\multicolumn{2}{|c|}{ Variables }} & \multicolumn{2}{|c|}{ Previous measurements } & \multicolumn{2}{|c|}{ Later measurements } & \multirow{3}{*}{$\begin{array}{c}\text { difference } \\
2.10\end{array}$} & \multirow{3}{*}{$\begin{array}{c}\mathrm{T} \text { value } \\
11.31\end{array}$} \\
\hline & & \multirow{2}{*}{$\begin{array}{c}\text { Average } \\
19.75\end{array}$} & \multirow{2}{*}{$\begin{array}{c}\text { torsion } \\
3.71\end{array}$} & \multirow{2}{*}{$\begin{array}{c}\text { average } \\
17.65\end{array}$} & \multirow{2}{*}{\begin{tabular}{|c|} 
torsion \\
2.71
\end{tabular}} & & \\
\hline \multirow{5}{*}{ self-perceptive } & Physical skill & & & & & & \\
\hline & Physical condition & 19.80 & 3.12 & 18.90 & 2.82 & .90 & 8.85 \\
\hline & $\begin{array}{c}\text { Physical } \\
\text { gravity }\end{array}$ & 20.90 & 4.19 & 18.67 & 3.43 & 2.23 & 13.78 \\
\hline & Physical self value & 21.80 & 4.75 & 16.40 & 2.95 & 5.60 & 22.48 \\
\hline & Physical skill & 22.25 & 4.36 & 17.05 & 2.98 & 5.20 & 22.84 \\
\hline
\end{tabular}

As shown from table there are significant for experimental, control group to later difference between later, previous measurements measurements in self-perceptive standard 


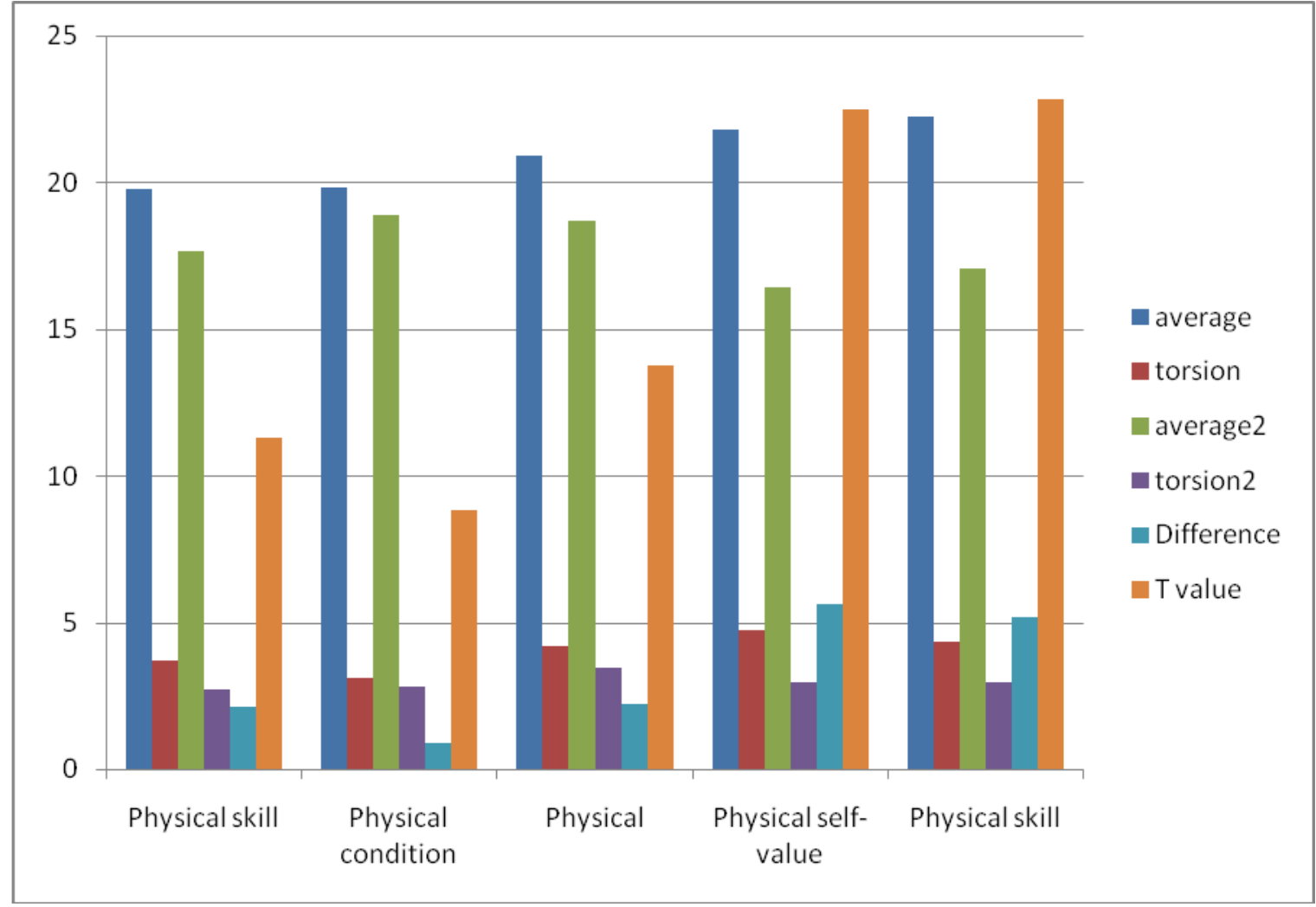

Table 4

Difference between controls, experimental group in later measurements for performance skill standard $N 1=N 2=30$

\begin{tabular}{|c|c|c|c|c|c|c|c|}
\hline \multirow{2}{*}{\multicolumn{2}{|c|}{ Variables }} & \multicolumn{2}{|c|}{$\begin{array}{c}\text { Previous } \\
\text { measurements }\end{array}$} & \multicolumn{2}{|c|}{ Later measurements } & \multirow{3}{*}{$\begin{array}{c}\text { difference } \\
1.23 \\
\end{array}$} & \multirow{3}{*}{$\begin{array}{c}\mathrm{T} \text { value } \\
13.81 \\
\end{array}$} \\
\hline & & Average & torsion & average & Torsion & & \\
\hline \multirow{3}{*}{ Performance skill } & Fall down(Ukemie) & 2.84 & .57 & 1.61 & .34 & & \\
\hline & $\begin{array}{l}\text { upper playing } \\
\text { (Nage.waza) }\end{array}$ & 7.98 & 1.48 & 5.51 & 1.05 & 2.47 & 20.28 \\
\hline & $\begin{array}{l}\text { ground playing } \\
\text { (Katame.waza) }\end{array}$ & 2.87 & .72 & 1.53 & .45 & 1.34 & 13.89 \\
\hline
\end{tabular}

As shown from table there is significant group for later measurements in performance difference between controls, Experimental skill standard 


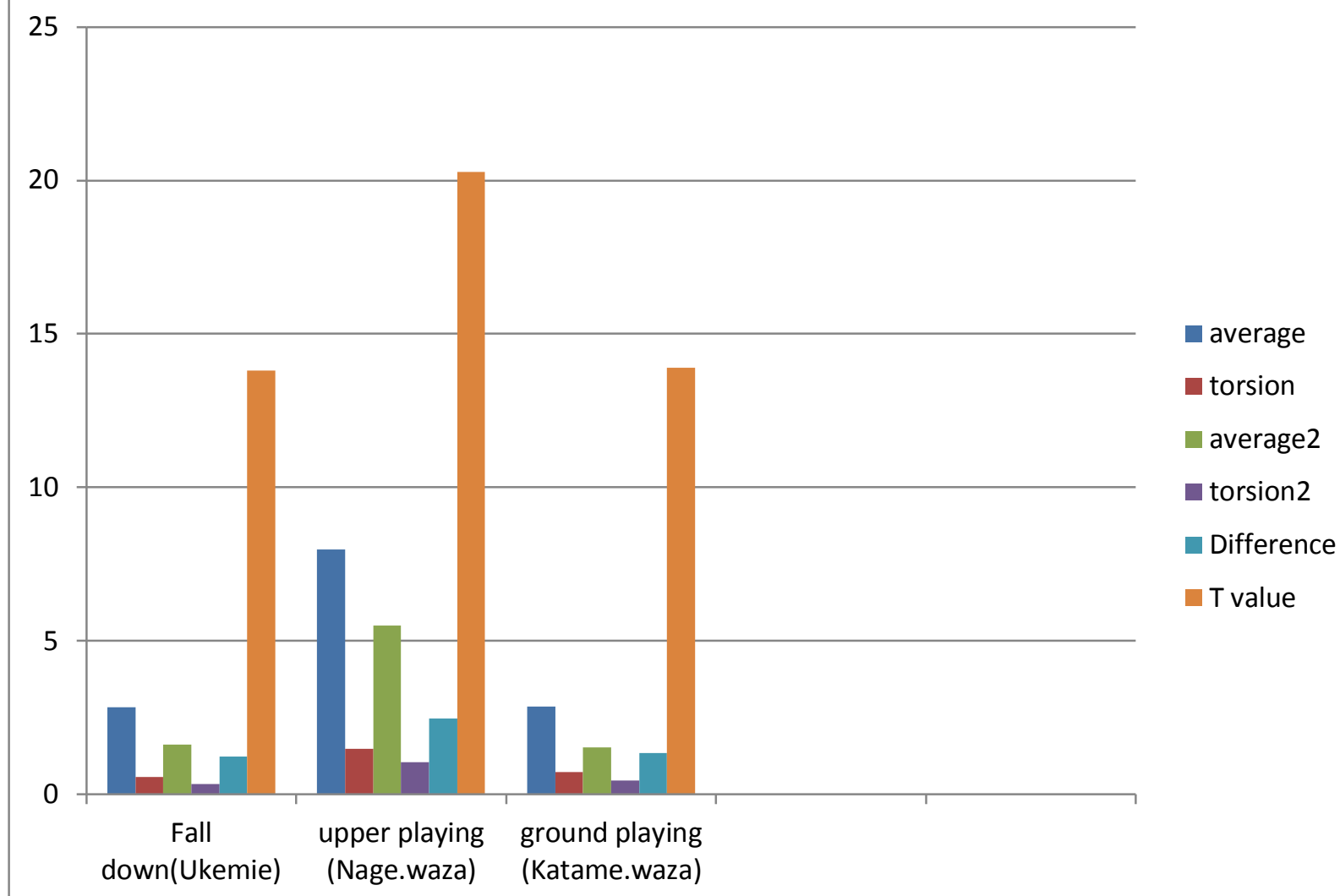

From Table (1) there are statistically significant differences between later measurements of the experimental, control group for experimental group in self-perceived standard.

The researcher returns that to the varying ratios in the self- perceived standard due to the activities of multiple intelligences of thrill element , excitement, allow for exploration, integrate new ideas with old ideas, view pictures and video use which increases the ability of students to perform correct responses of the skills expected exercise and preventing the separation of ideology and thus focus better on their performance. The use of learning activity in groups and collective thinking to solve the problem and given the opportunity to make the decision and opinion monopoly in the peerassessment and learning through exploration and individual learning also increases the ability of students to the full realization of the selfesteem.

This result is consistent with a study of (Manal Elgendy[ 3 ] that the use of teaching strategies on patterns of multiple intelligences help students to increase their motivation towards performance and sense of self-confidence as a result of working in small groups and the acquisition of collective experience.

Also the student realizing for the same affect in the level of performance both in the educational process or training, or competitive, making it the leading practical skills better and achieved the required performance of the learning process . Both of "Merkava, [ 4 ] , "Harvey. R.. Schifman [ 5 ]," and Johan Sabini [ 6 ] confirmed that the student with a self-high cognitive enable them to make the effort to achieve the level of required performance .

There is a close relationship between sport performance and self-perceptive.

"Mahmud Annan and others" [7 ] adds that when a person put in a exciting position, whether his view of it, it depends appreciation for the same position as well as the role played by the attribute of concern in the construction of his character happens if the pressure is balanced with the perceived one's awareness of its ability to respond.

From table (2) there are statistically significant differences between later, previous of the control group for later measurements selfperceptive standard..

The researcher referred that due to using of the traditional way for the control group, which did not follow variety in teaching methods and 
focuses on the scientific material only, did not follow individual differences among students, this technique was limited to explain the skill and give the form and frequency only, without exposure to any activity enriches ideas, works to attract attention and increases their motivation towards achievement.

This is in line with "Moore [8] that traditional education is the way for learning the skills but the learner will fell boring and it is slow to learn so the learner will get negative effect in selfconfidence, tension and reduces the motivation toward achievement

From table (3) there are statistically significant differences between the two sets of control and experimental group in the later measurements of the self-perceived standard for later measurements.

In the opinion of the researcher the self-esteem related positively with multiple intelligences activities. The students who has high level towards the achievement of success is available to have a great deal of the case of self-perceived as increase their self-motivation to get achievement, goals, strong desire to improve, and try seriously to be able to excel and create a unique achievements which increases their ability to focus on tasks required and have increased self-confidence and seek to enjoy the feeling and the desire to continue to reach the highest levels.

both of "Zainab Omar, Ghada Jalal" [9]confirmed that the diversity of activities , ways and means during teaching increases the motivation of achievement, focus the learner attention and make( him feel self-confident).

The study "Hend Said, Hbaalla Esam [10] referred to teaching mental skills in advanced and training on it from the starting sports activities, consistent with their age .

This is consistent with the pointed out of "Mohammed Allawi" [11] that the psychological traits contribute significantly to influence $f$ the players level."Welk G,Corbin [12] said that there is a clear, strong relation between the realization individual to the same sports and this is confirmed by "Osama Rateb" [13], Johan Sabini [6]
From table (4) there are statistically significant differences in later measurements of experimental and the control group for the latter group in the basic skills in question, and this means that the experimental group which studied the approach judo activities of multiple intelligences showed positively affected for the control group which studied the traditional way to learn the basic skills

This is consistent with the study of both the "Manal Elgendy" [3], "Melanie, Msheeal, Michael Kernodle" [14], "Cove koffs, S" [15] that teaching the activities of multiple intelligences was more positive in the classroom, in addition to the increase in students' grades..

This consistent with "Jabir Abdul Hamid" [16] that using of multiple intelligences activities increases the level of performance during learning activities, activate the mind of the student

this consistent with "Sfaa Saleh) [17] that educational programs that rely on addressing the multiple intelligences of learners increase their own way of motivation for learning through the senses thus improve performance level .

And also in accordance, " Armstrong. T [18] that multiple intelligences activities are more

effective in delivery, installation information for learners.

Regarding the control group their grades was lower than the experimental group, researcher returns that to traditional method used, which is characterized by style lecture and explanation and the performance of the model and redundancy without the diversity of educational methods, which in turn provides the potential to provide appropriate educational opportunities for students, as it does not respect individual differences among students in natural smartness This is consistent with both the " Barker, K.l.et" [19], "Knez Fox [20]Koff,s-R[15] that using traditional way in training will lead to little progress in improving performance skills level.

\section{Conclusion}

1. The multiple intelligences activities which was used has a positive influence in the 
development of self-perceived standard with the students of the college.

2. The multiple intelligences activities proposed a positive influence on performance skills level in college students more than the traditional method.

\section{Recommendations}

1. Attention to diversity in teaching methods and choice of multiple intelligences according activities according to the capabilities and tendencies of the students.

2. Individual differences among students must be taken into account and treat each student according to his level.

3. To use the theory of multiple intelligences in curriculum planning, programs and proposed activities of the educational process.

4. Evaluation of physical education curricula in the light of the theory of multiple intelligences.

5. Do not rely on traditional education alone, but to go to the education of blow energy, and aims to activate the intellectual abilities of students and motivate them to continue to study and life through the forms of education appropriate to the requirements of practical life.

\section{References}

1. Amin Fawzy, Ahmad (2006):Sports psychology (concepts and application)2nd edition-dar elfeker elaraby.Cairo.pp:123

2. Ibrahim Torfa, Murad (2001): - Judo between theory and application, , Cairo.pp:129

3. Elgendy, Manal (2006):- Teaching curriculum developer rhythm strategies based on the theory of multiple intelligences and measure its impact on learning outcomes, $\mathrm{PhD}$, Faculty of Physical Education

4. Production, Mercava (1999): Self perception \& Potential, Cooperation nd.pp:167

5. Harvey .R.Schifman,(1996):Sensation and Perception an integrated approach, wiley \& sons, Inc, U.S.A.pp:168

6. Sabini, Johan (1995) : Social Psychology, W.W. Norton \& Company, New York.pp:156
7. Abdel-Fattah Annan, Mahmoud (1955): The Psychology of Physical Education and Sports, dar elfeker elaraby-Cairo.pp:124

8. Moore.R.E.(1996): Effect of the use of Two deferent Teaching style of motor skill acquisition of fifth grade students volley ball, east taxes state university.

9. Ali omar, Zainab , Abdel-Hakim, Ghada, (2008): methods of teaching physical education (theoretical and practical applications), dar elfeker elaraby Cairo.pp:159

10. Saeed Ali, Hind, alla Essam El-Din, heba (2009): the impact of a training program on psychosocial skills for children young people from 9-10 years at the level of their performance in the sport of swimming, Scientific Conference of the Fourth International, "Recent trends of Sports Science in the light of the labor market", Faculty of Physical Education, Assiut University.

11. Hassan Allawi, Mohammad (2007): Introduction to sports psychology, 7th edition- -, markz el ketab for publication, Cairo.pp:1292Armstrong ,T,2009: Multiple intelligence in the Classroom, 2nd edition Alexandria , Virginia, (ASCD).pp:215

12. WelkG .J,Corbin C.B ,Lewis .L.A(1995): Physical self.perception of high school athletes pediatric,exercise, science,champaign.pp:178

13. Kamel Rateb, Osama (1955): Psychological skills training and their application in sport field- edition-dar elfeker elaraby-Cairopp:120.

14. Mitchell, Melanie, Kermode, Michael (2003): Using Multiple Intelligences to Teach Tennis, Journal of Physical Education, Recreation and Dance.pp:213

15. Koff,s-R(.2003): why the multiple intelligence? , Basic, Journal- of Dance Education, andvoerpp:134.

16. Abd elhamed gaber, Gaber (2003): Multiple intelligences understanding (developmentgeneralization) dar elfeker elarabyCairo. Pp:145

17. Saleh Huussen, Safaa(.2010): Effect of using the activities of multiple intelligences to learn some basic skills in kata and level of harmonic behavior of the mentally Handicapped , peocedie- social and behavioral sciences 
journal,

Availableonline:http://www.sciencedirect .com

18. Armstrong ,T,(2009): Multiple intelligence

in the Classroom, 2nd edition Alexandria , Virginia, (ASCD).pp:215
19. Barker ,K.l.et ,(2003) : Body image for the lower_ lims amputee master thesis , Columbia university..

20. Kenneth.R.Fox,(1996): The physical selfperception profile, Department of physical education, Northern Illinois university, New York.pp:215 